\title{
COMPARING FORMULA METHODS OF TREE APPRAISAL
}

\author{
by Gary Watson
}

\begin{abstract}
Values produced by formula methods of tree appraisal used in five different countries were compared (CTLA) - U nited States, Standard Tree Evaluation M ethod (ST EM ) - N ew Z ealand, H elliwell-Great Britain, N orma Granada-Spain, and Burnley-Australia). $\mathrm{N}$ ine individuals appraised the same six trees using all five methods. The CTLA and $\mathrm{H}$ elliwell methods consistently produced the lowest values, and the N orma Granada method values were most often the highest. There was a strong relationship between variation among appraisers and the mathematical operations used in calculating the formula values. The $\mathrm{H}$ elliwell method, which multiplies all of the rated factors together, consistently produced the highest variation among appraisers. ST EM, which adds all the factors together, consistently produced the lowest variation among appraisers. Minimizing the number of multiplication operations used in the formulas is an effective way of reducing appraiser variation, but in doing so, the influence of individual factors may be diminished too much.

Key Words. Tree appraisal; tree value; formula method; CTLA.
\end{abstract}

The value of large landscape trees is not easily established. $\mathrm{R}$ eplacement cost is the most direct way to establish the value of a tree. Though even large mature trees can sometimes be transplanted successfully, doing so can require extraordinary effort and cost. At some point, a tree becomes too large to be replaced practically with an equivalent one. If a tree cannot be replaced in kind, what are the alternatives?

The most common and widely used method of establishing the value of large trees worldwide is through the use of formulas. Two basic types of formulas are used. The first establishes an initial value based primarily on size, and then adjusts this value (usually down if less than perfect) for factors such as condition (vigor, structure, health, etc.), location (setting, real estate value, function, visibility, etc.), species quality, and special situations (historic significance, etc.). T he other type of formula uses a point rating system for these factors (points can be added or multiplied together) with a monetary factor introduced at the end. $W$ ith this approach, size is usually one of several equally weighed factors and has less influence on appraised value. 0 ther factors, such as health condition, position in the landscape, and special factors, are also emphasized differently in the various formulas.

Formulas are usually linked to regional market conditions through the incorporation of the cost of nursery stock. This assumes there is a direct relationship between the cost of nursery stock and the value of larger trees W hen a monetary value not linked to nursery prices has been specified in the formula, it has been determined by consensus. O nly one method still uses this approach (H elliwell 2000).

Little has been published on how appraised values produced by the different formula methods compare. The five methods chosen for comparison in this study exhibit a wide variety of approaches that seem to be adaptable for use outside the geographic region where they were developed.

\section{METHODS \\ Description of Formula Methods}

Each of the formula methods chosen had a somewhat different approach to tree appraisal. Simplified descriptions of each method (and country of origin) are given below to help the reader understand the basic concepts of each method. $R$ eaders with an interest in the details of each method are referred to the original publications.

Guide for Plant Appraisal, 8th edition (United States). This method has been widely used since 1951, and a 9th edition was published in 2000 (CT LA). T he 8th edition (CTLA 1992) was the most recent edition when this study was conducted. Its method is based on a measurement of the cross-sectional area of the tree trunk at $1.4 \mathrm{~m}$ ( $4.5 \mathrm{ft}$ ) multiplied by a monetary value per square inch. This maximum value is then reduced by factors for species quality, condition, and location in the landscape ( 0.0 to 1.0 for each factor). The value per square inch is based on the cost of the largest commonly available trees (per square inch of trunk area) at regional nurseries. (For simplicity's sake, certain complexities of the 8th edition are not discussed here but were included in the calculations.) The cost per square inch and species rating were determined by a regional committee. This method will be referred to as the CT LA method. 
The simplified formula of the CT LA method is

Appraised value $=\left(\right.$ trunk area $\left(\right.$ in $\left.^{2}\right) \times$ basic price $/$ in $\left.^{2}\right) \times$ species $\times$ condition $\times$ location

Revised Burnley Method (Australia). Developed at the Victorian College of Agriculture and $\mathrm{H}$ orticulture Limited, Burnley $\mathrm{C}$ ampus, this method was first published in 1988 (M cGarry and Moore) and revised in 1991 (Moore). It is similar in concept to the CTLA method, and it is also based on tree size and a unit monetary value. Tree size is measured as volume of the tree approximated by an inverted cone. The tree volume is multiplied by the cost per cubic meter of retail nursery stock (presumably of the same species). This maximum value is then reduced by factors for life expectancy (0.5 to 1.0), form and vigor (0.0 to 1.0), and location (0.4 to 1.0). Like the CTLA method, all factors reduce the base value. U nlike the CT LA method, not all factors can bring the value to zero. This method will be referred to as the Burnley method. The simplified formula is

Appraised value $=$ tree volume $\times$ base value $\times$ life expectancy $\times$ form and vigor $\times$ location

Amenity Valuation of Trees and Woodlands (Great Britain). Based on Helliwell (1967) and most recently revised in 2000 (H elliwell), this method focuses on visual amenity and rates seven factors at 1 to 4 points each (occasionally less than 1). A low rating of 1 for any factor would have no impact on the appraised value. The factor points are multiplied together and then by an assigned monetary value per point (f 14 in 2000 revision). The U.S. equivalent in dollars was used for the calculations in this study. This method will be referred to as the H elliwell method.

Appraised value $=$ tree size $\times$ life expectancy $* \times$ importance in the landscape $\times$ presence of other trees $\times$ relation to setting $\times$ form $\times$ special factors $\times f 14$

*T he published method includes a procedure for determining tree age, but this method did not work in northern Illinois when tested on trees of known age. Instead, appraisers were asked to estimate life expectancy by whatever method they felt appropriate, which is also done in the Burnley and $\mathrm{N}$ orma Granada methods.

Standard Tree Evaluation Method-STEM (New Zealand). This method was new in 1996 (Flook). Like the Helliwell method, it uses a point system to rate 20 tree attributes ( 3 to 27 points for each attribute) in three general categories of condition, amenity, and notable (special merit) qualities. The attributes rated are

Condition

Form

(Frequency of) occurrence

Vigor and vitality

Function (usefulness)

Age (years)

Amenity

Stature (greater of height or spread)

Visibility $(\mathrm{km})$

Proximity (presence of other trees)

Role

Climate

N otable (only for trees over 50 years old)

Stature

Feature (exceptionally large/ special visual interest)

Form (outstanding example/ specimen)

$\mathrm{H}$ istoric

Age $(100$ years +$)$

Association (with event, person, tradition, etc)

Commemoration

R emnant (of a native ecosystem)

R elict (survived change from natural to artificial environment)

Scientific

Source (quality of genetic derivation)

R arity (of species)

Endangered

The point total is then multiplied by the wholesale cost of a 5-year-old tree (no indication of species specificity). To that is added the wholesale cost of planting the tree and the cost of maintaining the tree until it reaches the same age as the tree that was lost. Finally, the figure is multiplied by a factor to convert from wholesale to retail (doubling suggested).T his method will be referred to as ST EM .

Appraised value $=$ total points $(540$ possible $) \times$ wholesale cost + planting cost + maintenance cost] $\times$ retail conversion factor (2 suggested)

Norma Granada (Spain). This method was first published in 1990 and revised in 1999 (A sociacion Española de Parques y Jardines Publicos). It uses a series of tables dealing with tree species (growth rate and longevity) and size factors to determine a "value factor" (valores del factor). This value factor is multiplied by the wholesale cost of a nursery-grown 
tree to determine the initial value. Like the CT LA and revised Burnley methods, factors related to tree condition and position in the landscape are used to adjust this value. U nlike these other two methods, condition rating can either increase or decrease the value (a tree in average condition will have no effect). Life expectancy and "extrinsic" attributes of the tree can only increase the basic value. The maximum theoretical value of the tree is eight times the initial value. This method will be referred to as the N orma Granada method.

Appraised value $=($ value factor $\times$ wholesale $\cos x \times$ condition) $\times[1+$ life expectancy + (aesthetic value + species rarity + site suitability + extraordinary)]

\section{Methods Comparison in the Field}

O n September 23, 1999, nine individuals with professional interest in the value of urban trees independently appraised six trees located on the grounds of The M orton A rboretum in Lisle, Illinois, U.S., using the five methods. B efore beginning the appraisals, the five formula methods chosen for the exercise were reviewed.

Trees of six different species were chosen for the methods comparison study. The species included were pin oak ( $Q$ ueras palustris), A merican elm (U Imus americana), linden (T ilia spp., an unusual species that would not have been identifiable by the appraisers), Kentucky coffeetree ( $G$ ymnodadus dioica), European beech (Fagus sylvatica), and European ash (F raxinus excelsior). The trees represented a broad spectrum of those that could be encountered in the landscape, and they included contrasts in size, species quality, and landscape position (Table 1). The six appraisers were not given this information until after the appraisals were complete.
A ppraisers were provided with a field data sheet for each tree for recording the data required by each method. There was a separate column for each method. Similar data required by each method were organized in rows so that they could be recorded at the same time (e.g., life expectancy).

Information related to size or species quality that was readily measurable, or available as part of the published method, was al ready entered on the data sheet to facilitate the evaluation process (Table 1). W holesale nursery stock prices required by some formulas were averaged from up to four regional (northeast Illinois) nurseries for each species and size required. Where no species-specific prices were required, an average of the cost of all six species included in the study was used (Table 2). R etail costs were established as twice the wholesale cost. Annual maintenance cost for ST EM was calculated as $14 \%$ of the retail cost of the tree and planting, based on the method used by local landscape maintenance contractors (personal communication with a local contractor). The species rating, cost per square inch of trunk area, and installed tree cost used in the CTLA method were determined by a regional committee for northeast Illinois.

For each species, appraised values resulting from the different methods were compared using one-way AN OVA ( $P=0.05)$. Separation of means was tested using the Student- $N$ ew man- Keuls test $(P=0.05)$. The coefficient of variation [(standard deviation/mean) $\times 100$ ] was used to compare the magnitude of variation in appraised values among the methods.

In real situations, trees are usually appraised by two appraisers, one from each of the opposing sides. To reflect this type of realistic appraisal situation, the average differ-

Table 1. Species and characteristics of trees appraised.

\begin{tabular}{|c|c|c|c|c|c|c|c|}
\hline Species & $\begin{array}{l}\text { Species selection } \\
\text { criteriaz }^{z}\end{array}$ & $\begin{array}{l}\text { Species } \\
(C T L A)^{y}\end{array}$ & $\begin{array}{l}\text { Dbh } \\
\text { (cm/in.) } \\
(\mathrm{CTLA})\end{array}$ & $\begin{array}{l}\text { C rown size } \\
\text { (H elliwell) }\end{array}$ & $\begin{array}{l}\text { Crown size } \\
\text { (STEM) }\end{array}$ & $\begin{array}{l}\text { Volume }\left(\mathrm{m}^{3}\right) \\
\text { (Burnley) }\end{array}$ & $\begin{array}{l}\text { Value factor } \\
\text { (N orma G ranada) }\end{array}$ \\
\hline $\begin{array}{l}\text { Pin oak } \\
\text { (Q uercus palustris) }\end{array}$ & $\mathrm{H}$ igh species quality & 0.7 & $84(33)$ & 3 & 3 & 877 & 738 \\
\hline $\begin{array}{l}\text { A merican elm } \\
\text { (U Imus americana) }\end{array}$ & Low species quality & 0.2 & $79(31)$ & 3 & 3 & 731 & 444 \\
\hline $\begin{array}{l}\text { Linden } \\
\text { (T ilia spp.) }\end{array}$ & Large trunk diameter & 0.7 & $119(47)$ & 3 & 3 & 1,062 & 989 \\
\hline $\begin{array}{l}\text { K entucky coffeetree } \\
\text { (G ymnocladus dioica) }\end{array}$ & Small tree & 0.8 & $15(6)$ & 1.5 & 1 & 35 & 23 \\
\hline $\begin{array}{l}\text { European beech } \\
\text { (F agus sylvatica) }\end{array}$ & $\begin{array}{l}\text { Prominent landscape position; } \\
\text { large crown }\end{array}$ & 0.7 & 94 (37) & 4 & 3 & 966 & 985 \\
\hline $\begin{array}{l}\text { European ash } \\
\text { (F raxinus europea) }\end{array}$ & $\begin{array}{l}\text { O bscure landscape position; } \\
\text { large crown }\end{array}$ & 0.6 & $94(37)$ & 4 & 3 & 1,253 & 871 \\
\hline
\end{tabular}

${ }^{\mathrm{z}} \mathrm{N}$ ot included on data sheet.

yD etermined by local committee.

×From table in method, based on species and size. 
Table 2. Nursery tree purchase and planting costs used for formulas, in U.S. dollars.

\begin{tabular}{|c|c|c|c|c|c|c|}
\hline & $\begin{array}{l}\text { Pin oak } \\
\text { (Q ueraus } \\
\text { palustris) }\end{array}$ & $\begin{array}{l}\text { American elm } \\
\text { (U Imus } \\
\text { americana) }\end{array}$ & $\begin{array}{l}\text { Linden } \\
\text { (Tilia spp.) }\end{array}$ & $\begin{array}{l}\text { Kentucky } \\
\text { coffeetree } \\
\text { (G ymnocladus } \\
\text { dioica) }\end{array}$ & $\begin{array}{l}\text { European beech } \\
\text { (F agus sylvatica) }\end{array}$ & $\begin{array}{l}\text { European ash } \\
\text { (F raxinus } \\
\text { excelsior) }\end{array}$ \\
\hline \multicolumn{7}{|l|}{ CTLA } \\
\hline $\begin{array}{l}\text { Basic price/ in } 2 \\
\text { CTLA }\end{array}$ & 36 & 36 & 36 & 36 & 36 & 36 \\
\hline $\begin{array}{l}\text { Installed tree cost } \\
\text { STEM }\end{array}$ & 570 & 570 & 570 & 570 & 570 & 570 \\
\hline $\begin{array}{l}\text { 6- } \mathrm{cm} \text { tree wholesale } \\
\text { STEM }\end{array}$ & 167 & 167 & 167 & 167 & 167 & 167 \\
\hline $\begin{array}{l}\text { Planting cost } \\
\text { Burnley }\end{array}$ & 283 & 283 & 283 & 283 & 283 & 283 \\
\hline $\begin{array}{l}\text { 1- } m^{3 *} \text { tree retail } \\
\text { Norma Granada }\end{array}$ & 204 & 170 & 170 & 200 & 254 & 190 \\
\hline 6- $\mathrm{cm}$ tree wholesale & 102 & 85 & 85 & 100 & 127 & 95 \\
\hline
\end{tabular}

*A $1 \mathrm{~m}^{3}$ tree $=1.5$ - in. caliper, 10 to $12 \mathrm{ft} \mathrm{tall,} 2.5$ to $3.5 \mathrm{ft}$ wide as per AN SI Z60.1 standard.

ence (percentage) in appraised value between pairs of appraisers was calculated. This was done for each tree by averaging the difference between all possible combinations of two appraisers, dividing by the mean appraised value, and then multiplying by 100 .

\section{RESULTS AND DISCUSSION}

The lowest appraised values were always from CTLA or $\mathrm{H}$ elliwell (Table 3). The values produced by these two methods were not different from each other for three trees, and for the other three trees, neither was always greater. The ST EM and Burnley methods were not significantly different from each other on four of the six trees and were consistently much higher than CTLA or H elliwell. N orma Granada produced the highest values of all the formula methods for three trees and values similar to STEM and Burnley for two trees.

The high appraised values produced by the N orma Granada method may be related to using the method outside of Spain. C oefficients of unexplained, and perhaps local, origin are used to generate the "value factors." No other method had such a component to the formula. W hen used outside of Spain, an adjustment of this "value factor" for other growing conditions and economic situations (price of nursery trees) may be necessary to produce completely valid appraised values.

STEM seems to be oriented primarily towards large and "notable" trees. Though this is not specifically mentioned, none of the numerous examples in the publication are small trees. This method produced an unrealistically high value for the small coffeetree, and this value was not considered further in the comparisons. The other formula methods seem more suited for use on small trees.
The range of appraised values for the same tree using different methods varied widely: as low as a 12-fold difference between low and high for the beech (7.4-fold for the coffeetree, not including ST EM ), and as high as 27.5 -fold for the linden. The large difference among values for the linden seems to be mostly due to differences in the relative weighting of the key factors of size and species quality in the formula methods. In the N orma Granada method, the high species rating and large trunk diameter contribute to the very high value $69 \%$ higher than the next highest value). In contrast, the $\mathrm{H}$ elliwell method does not consider species, and size is measured by crown area (relatively small for the linden relative to the trunk diameter), and this lowest value was $76 \%$ lower than the next lowest appraised value. For the beech, the relatively small difference between low and high values among all methods was due mostly to the relatively high lowest value. It was an impressive tree in a public place, and it fared well in both the CTLA and $\mathrm{H}$ elliwell methods. For all other trees, at least one of these methods produced a much lower value, increasing the difference between low and high considerably.

\section{Influence of Individual Factors}

Tree size. Trunk measurements are used to measure size in the CTLA and N orma G ranada methods and are presumably used as a proxy for crown size. $\mathrm{N}$ ot unexpectedly, the linden with the large trunk was the most valuable of the six trees using the CTLA method (Tables 1 and 3). This is the only method that uses cross-sectional trunk area (an exponential calculation) as the measurement of size. A rea increases much faster than diameter or circumference, and the value of trees increases rapidly with size. 


\begin{tabular}{|c|c|c|c|c|c|c|}
\hline $\begin{array}{l}\text { A ppraisal } \\
\text { method }\end{array}$ & $\begin{array}{l}\text { Pin oak } \\
\text { (Q uercus } \\
\text { palustris) } \\
\end{array}$ & $\begin{array}{l}\text { A merican elm } \\
\text { (U Imus } \\
\text { americana) }\end{array}$ & $\begin{array}{l}\text { Linden } \\
\text { (Tilia spp.) }\end{array}$ & $\begin{array}{l}\text { Kentucky } \\
\text { coffeetree } \\
\text { (G ymnodadus } \\
\text { dioica) } \\
\end{array}$ & $\begin{array}{l}\text { European beech } \\
\text { (Fagus sylvatica) }\end{array}$ & $\begin{array}{l}\text { European ash } \\
\text { (Fraxinus } \\
\text { excelsior) }\end{array}$ \\
\hline $\begin{array}{l}\text { CTLA }^{z} \\
\text { Helliwell } \\
\text { STEM } \\
\text { Burnley } \\
\text { N orma Granada }\end{array}$ & $\begin{array}{l}10,700 a^{y} \\
5,313 a \\
46,485 b \\
78,898 b \\
59,935 b\end{array}$ & $\begin{array}{l}2,000 \mathrm{a} \\
2,361 \mathrm{a} \\
37,812 \mathrm{~b} \\
26,096 \mathrm{~b} \\
40,360 \mathrm{~b}\end{array}$ & $\begin{array}{l}17,300 \mathrm{~b} \\
3,985 \mathrm{a} \\
48,402 \mathrm{c} \\
64,994 \mathrm{c} \\
109,928 \mathrm{~d}\end{array}$ & $\begin{array}{l}600 a \\
2,361 b \\
37,760 d^{x} \\
4,460 c \\
3,322 b\end{array}$ & $\begin{array}{l}13,900 \mathrm{a} \\
25,190 \mathrm{~b} \\
60,461 \mathrm{c} \\
122,950 \mathrm{~d} \\
167,212 \mathrm{e}\end{array}$ & $\begin{array}{l}5,700 \mathrm{a} \\
4,723 \mathrm{a} \\
42,822 \mathrm{~b} \\
46,661 \mathrm{~b} \\
87,068 \mathrm{c}\end{array}$ \\
\hline
\end{tabular}

${ }^{2} \mathrm{CTLA}$ method calls for rounding formula values to the nearest $\$ 100$.

Values followed by the same letter are not significantly different at $P=0.05$.

xSTEM is not intended for use on small trees.

The N orma Granada method also uses trunk circumference to measure size.The linden also had a high value using this method, but the linden was not the most valuable tree using N orma Granada (Table 3). For trunk diameters greater than $76 \mathrm{~cm}$ (30 in.), increases in the value factor are negligible with this method.T herefore, the appraised value of the linden with a substantially larger trunk diameter would not be expected to be greater than the four other trees also over $76 \mathrm{~cm}$ dbh based on size alone.

W ith the Burnley method, the size is measured as canopy volume, another exponential calculation. The linden had only the second largest crown volume (Table 1), but the ash with the largest crown was valued lower than the linden, and the beech with a sightly smaller crown than the linden was valued higher than the linden. The other factors apparently influenced value as much or more than size in the Burnley method.

The Helliwell method uses cross-sectional area of the crown to measure tree size. $U$ sing the size classes specified in the method, all five of the large trees fell into either the large or very large category. This resulted in only a one-point difference between trees, and size is one of seven factors multiplied together. Thus, size has relatively little influence on value. STEM uses a linear measurement of crown size, and again is one of many factors having relatively little influence on value.

Species. The influence of species quality on appraised value also varies with method. The largest difference due to species quality was found in the CTLA method. Pin oak and American elm are generally considered high and low species quality in the region ( 0.7 versus 0.2 rating, respectively, in the Illinois rating list) and were similar in size. The appraised values reflected this difference.

$\mathrm{N}$ either STEM nor the Helliwell method considers species directly, using only indirect species related measures such as longevity and rarity, and the difference between appraised values of the oak and the elm were not great. Species quality influences the Burnley method through indirect measures and also the variation in the price of nursery stock, but this does not account for the threefold difference in value between the elm and oak. 0 ther factors apparently had a greater effect.

For the N orma Granada method, both the value factor [e.g., 439 to 955 points for a $76-\mathrm{cm}$ (30-in.) dbh tree] and price of nursery stock are influenced by species. The $50 \%$ difference in value exhibited between the elm and oak was in line with differences in value factor $(60 \%)$ and the nursery stock price $(20 \%$, Table 1$)$.

Location. The beech and ash were examples of similar size trees in prominent and obscure locations in the landscape. The Helliwell method produced the largest difference (more than fivefold) in appraised values. Three of the seven factors rated in this method are related to location. Five of the 20 factors rated in STEM (probably no more than a total of 12 in practice because the participating appraisers rarely rated more than one or two of the "notable" category factors) are related to location, but the difference between the two trees was small (1.4-fold). It was not clear why the difference between the two trees was so small. It may be because of the many equally weighted factors that are simply added together and the resulting inability of any one factor to have a large influence in value. The difference between these two trees using the other three methods was 1.9- to 2.6-fold and very much in line with the location components of the formulas.

Condition. No trees in poor health were available for testing the formulas. Analysis of the formulas suggests an effect similar to location for CTLA, Burnley, and ST EM. The N orma Granada method is unique in that condition factors can either increase or the decrease 
basic value (0 to 200\%). An average condition has little or no effect. Condition may affect values produced by the $\mathrm{H}$ elliwell method the least, because condition or health is not rated directly.

Special Factors. The degree to which "notable" or "extraordinary" factors influence the appraised value varies U $p$ to 10 different "notable" factors could be used in STEM , contributing up to $50 \%$ of the total points in extreme cases. O n a practical basis, ratings in all categories would be unlikely on any single tree. The examples of "notable" trees used in the STEM publication (Flook 1996) generally scored points in 3 to 5 of the 10 categories, or less than $25 \%$ of the total points for the tree. Appraisers participating in this study rarely rated more than one or two of the "notable" category factors, increasing the appraised value very little. The N orma Granada and $\mathrm{H}$ elliwell methods treat special factors as a single specific factor and could have about the same influence on appraised value as condition or location. The CTLA method treats special factors only as a consideration in determining the location rating and would have minimal influence on appraised value. Special factors are not mentioned in the Burnley method.

\section{Differences Among Appraisers}

The differences among appraisers using the same formula method are sometimes large (Kielbaso 1979; R ey-Lescure 1985; Abbot and M iller 1991; Helliwell 2000). The coefficient of variation ( $\mathrm{CoV}$ ) is a good indicator of the variation within each method due to the individual appraisers. For every tree, the highest CoV was associated with the Helliwell method and the lowest with STEM (Table 4). There seems to be strong relationship between the $\mathrm{CoV}$ and the mathematical operations used in calculating the values. Both H elliwell and STEM use a system that assigns points to various attributes (size, health, aesthetics, etc.).T he Helliwell method multiplies all seven attributes together, while STEM adds up to 20.T he C OV is seven times higher in the Helliwell method. U sing the Helliwell method, if two appraisers are as little as one point different on a single factor, with everything else being identical, the appraised values may differ by up to $100 \%$. The CoV of the other three methods are intermediate and similar. Each method uses two or three multiplication operations in the formula.

Though multiplication increases variation, using it does allow for the appraised value to be zero if a low rating of a single factor should render the tree worthless. For example, if the health of a tree is very poor, or it is extensively decayed and represents a hazard, it may have no value. A zero condition/ health rating would accomplish this when the condition/ health factor is multiplied against the other factors, but not if added to the others. Some provision for a zero appraised value is probably needed in methods not multiplying factors together.

Some variation is undoubtedly due to the largely subjective evaluation of tree attributes by the appraiser. The amount of guidance provided for assigning numeric values to factors related to health condition and to aesthetic and functional attributes varies by method. Some provide detailed rating scales or tables; others rely heavily on the expertise and experience of the appraiser.

Inconsistency between appraisers has long been a concern. Excessive variation between appraisers (using the same method) can undermine the credibility of the appraisal method. The CTLA method has been criticized for exces sive differences between appraisers (K ielbaso 1979; R eyLescure 1985; Abbot and Miller 1991). These authors considered differences as great as twofold to be acceptable. The Helliwell method itself (Arboricultural Association 1994; H elliwell 2000) suggests that a twofold difference between two appraisers would be acceptable.

These comments on "acceptable difference" were made in the usual context of two appraisals of the same tree. The average difference between two appraisers may be a better method of judging variation than the CoV. Variation seems quite acceptable for all trees and methods when viewed this way (Table 5). For example, if two individuals appraised the pin oak using the CTLA method, the difference between them would have averaged $\$ 45$ for every $\$ 100$, well within the acceptable range of a twofold difference. $U$ sing

Table 4. Coefficient of variation.

\begin{tabular}{|c|c|c|c|c|c|c|}
\hline $\begin{array}{l}\text { Appraisal } \\
\text { method }\end{array}$ & $\begin{array}{l}\text { Pin oak } \\
\text { (Q uercus } \\
\text { palustris) }\end{array}$ & $\begin{array}{l}\text { A merican elm } \\
\text { (U Imus } \\
\text { americana) }\end{array}$ & $\begin{array}{l}\text { Linden } \\
\text { (T ilia spp.) }\end{array}$ & $\begin{array}{l}\text { Kentucky } \\
\text { coffeetree } \\
\text { (G ymnocladus } \\
\text { dioica) }\end{array}$ & $\begin{array}{l}\text { European beech } \\
\text { (F agus sylvatica) }\end{array}$ & $\begin{array}{l}\text { European ash } \\
\text { (F raxinus } \\
\text { excelsior) }\end{array}$ \\
\hline CTLA & 37 & 36 & 31 & 29 & 38 & 49 \\
\hline H elliwell & 84 & 108 & 109 & 157 & 98 & 85 \\
\hline STEM & 13 & 11 & 15 & 26 & 18 & 12 \\
\hline Burnley & 49 & 42 & 37 & 22 & 48 & 58 \\
\hline N orma G ranada & 27 & 38 & 29 & 29 & 28 & 51 \\
\hline
\end{tabular}


the $\mathrm{H}$ elliwell method, the difference would have averaged $\$ 88$ for every $\$ 100$ of appraised value-greater, but still within the limits of acceptability.

Though the average difference between two appraisers seems acceptable for all methods, it is possible that the two appraisers producing the highest and lowest values could be called upon to appraise the same tree. Again with the pin oak as an example, using the CTLA method, the high and low appraisers were $\$ 109$ apart for every $\$ 100$ of appraised value- double the average difference and just over the acceptable twofold difference. $U$ sing the $H$ elliwell method, the maximum difference would have averaged $\$ 275$ for every $\$ 100$ of appraised value - far too high to be acceptable.

Both average and extreme differences between appraisers may be somewhat greater in real-life situations for a variety of reasons. Skills and experience of appraisers can vary more widely than they did for this group of experts. This group was also supplied with identical information simultaneously. In real-life situations, appraisers are often provided information separately and may not be working from identical background information.

\section{CONCLUSIONS}

Though it is tempting to try to compare the methods to each other, it was not the intention of this project to judge or rank them. When comparing the appraised values among the five methods, it would appear that a tree is worth approximately seven times more in $\mathrm{N}$ ew Zealand and Australia than it is in the U nited States and Great Britain, and perhaps even more in Spain. $C$ an this be true? All the methods seem to have been adopted widely in their country of origin. Communication with the authors and regular users of each of the formulas indicates that each method is well respected and has been used successfully in court. If the higher tree values are accepted in some countries, the reason for it is not evident from this study.

Variation among appraisers has been a long-standing concern. If the difference between appraisers is consistently too great, then the credibility of the method of appraisal can diminish. The average difference between appraisers was usually within the twofold difference considered acceptable by previous authors, but this acceptable difference is probably higher than that in other fields of appraisal. Subjectivity will always exist as appraisers are asked to make judgments on factors that are not easily or directly measurable or comparable. The number of subjective factors varies among methods, as does the guidance provided in rating these factors. H ow these subjective ratings are used in the formulas can either diminish or exaggerate the variation among appraisers. M ultiplication increases variation; addition minimizes it. Though more explicit rating scales may help in some cases, the most effective way of reducing appraiser subjectivity appears to be by minimizing the number of multiplication operations used in the formulas.

Appraised values should reflect differences in size, condition, longevity, amenity, and other factors, but what is the appropriate magnitude of this difference? That will have to be determined by the appraisal community, but for the first time we now have information on the range that exists between these different methods.

O ne thing all formula methods seem to have in common is that they are revised or replaced on a regular basis. This may be a reflection of the difficulty of establishing a value for something that is not normally bought and sold. This comparison of methods may help to provide insight as to the strengths and weaknesses of each method that could be used in future revisions of each.

Table 5. D ifferences in appraised values between two appraisers.

\begin{tabular}{|c|c|c|c|c|c|c|c|c|c|c|c|c|}
\hline \multirow{2}{*}{$\begin{array}{l}\text { Appraisal } \\
\text { method }\end{array}$} & \multicolumn{2}{|c|}{$\begin{array}{l}\text { Pin oak } \\
\text { (Q uercus } \\
\text { palustris) }\end{array}$} & \multicolumn{2}{|c|}{$\begin{array}{l}\text { A merican elm } \\
\text { (U Imus } \\
\text { americana) }\end{array}$} & \multicolumn{2}{|c|}{$\begin{array}{l}\text { Linden } \\
\text { (T ilia spp.) }\end{array}$} & \multicolumn{2}{|c|}{$\begin{array}{l}\text { K entucky } \\
\text { coffeetree } \\
\text { (G ymnodadus } \\
\text { dioica) }\end{array}$} & \multicolumn{2}{|c|}{$\begin{array}{l}\text { European beech } \\
\text { (F agus sylvatica) }\end{array}$} & \multicolumn{2}{|c|}{$\begin{array}{l}\text { European ash } \\
\text { (F raxinus } \\
\text { excelsior) }\end{array}$} \\
\hline & $\mathrm{Avg}^{2}$ & $\mathrm{R}_{\text {ange }}{ }^{\mathrm{y}}$ & Avg & $\mathrm{R}$ ange & Avg & $\mathrm{R}$ ange & Avg & $\mathrm{R}$ ange & Avg & $\mathrm{R}$ ange & Avg & $\mathrm{R}$ ange \\
\hline CTLA & 45 & 109 & 42 & 105 & 38 & 95 & 35 & 93 & 46 & 107 & 57 & 125 \\
\hline Helliwell & 88 & 275 & 107 & 332 & 112 & 349 & 129 & 491 & 112 & 294 & 96 & 252 \\
\hline STEM & 15 & 39 & 12 & 33 & 18 & 49 & 28 & 86 & 21 & 61 & 14 & 39 \\
\hline Burnley & 58 & 130 & 50 & 121 & 44 & 120 & 24 & 76 & 57 & 140 & 68 & 153 \\
\hline N orma Granada & 33 & 79 & 45 & 103 & 34 & 92 & 33 & 101 & 33 & 71 & 56 & 166 \\
\hline
\end{tabular}

${ }^{2}$ Average difference in appraised values between all possible combinations of two appraisers/mean appraised value $\times 100$.

yD ifference between highest and lowest appraised values by nine individual appraisers for each method/mean appraised value $\times 100$. 


\section{LITERATURE CITED}

A bbot, R .E., and K.C. M iller. 1991. U tility tree damage claims. J. Arboric. 17:113-116.

A rboricultural A ssociation. 1994. Amenity Valuation of Trees and Woodlands (2nd ed.). Arboricultural Association, R omsey, $\mathrm{H}$ ants, U nited Kingdom.

Asociacion Española de Parques y Jardines Publicos. 1999. M etedo ParaValoración de Árboles y A rbustos 0 rnamentales. N orma Granada. Asociacion Española de Parques y Jardines Publicos, M adrid, Spain.

C ouncil of Tree \& Landscape A ppraisers. 1992. Guide for Plant A ppraisal (8th ed.). International Society of Arboriculture, Champaign, IL.

C ouncil of Tree \& Landscape A ppraisers. 2000. Guide for Plant Appraisal (9th ed.). International Society of Arboriculture, Champaign, IL.

Flook, R. 1996. A Standard Tree Evaluation M ethod (ST EM). $\mathrm{R}$ on Flook, Tahunanui, $\mathrm{N}$ elson, $\mathrm{N}$ ew $\mathrm{Z}$ ealand.

H elliwell, D.R . 1967. The amenity value of trees and woodlands. Arboric. J. 1:128-131.

H elliwell, D.R . 2000. A menity Valuation of Trees and Woodlands (rev. ed.). A rboricultural Association, R omsey, $\mathrm{H}$ ants, $\mathrm{U}$ nited Kingdom.

Kielbaso, J.J. 1979. Evaluating trees in urban areas. J. Arboric. 5:70-72.

M CG arry, P.J., and G.M . M oore. 1988. The Burnley method of amenity tree evaluation. A ust. J. A rboric. 1(1):19-26.

M oore, G.M . 1991. A menity tree evaluation: A revised method, pp 166-171. In The Scientific M anagement of Plants in the U rban Environment. Proceedings of the Burnley $C$ entenary Conference, Centre for U rban Horticulture, Melbourne, Australia.

R ey-Lescure, E. 1985. The location factor in evaluating shade trees and the replacement value in appraising hedges: Two proposals. J. Arboric. 11:113-136.

Acknowledgments T his project was supported, in part, by a grant from the USDA Forest Service $\mathrm{N}$ orth Central Experiment Station. A special thanks to Colin Bashford, Patrick Buckley, John D wyer, Laurence $\mathrm{H}$ all, James Ingram, James Kielbaso, R.J. Laverne, D avid N owak for participating as appraisers.

The $\mathrm{M}$ orton A rboretum

Lisle, IL, 60532, U.S.
Résumé Les valeurs monétaires produites à partir des méthodes d'évaluation de cinq pays différents ont été comparées entre elles (CTLA aux États-U nis, STEM en N ouvelle-Zélande, $\mathrm{H}$ elliwell en Grande-Bretagne, $\mathrm{N}$ orma Granada en Espagne, Burnley en Australie). N euf personnes ont évalués les six mêmes arbres en utilisant chacune des cinq méthodes Les méthodes CTLA et Burnley produisaient sans exception les valeurs les plus basses, et la méthode d'évaluation $\mathrm{N}$ orma Granada donnait souvent celles qui étaient les plus élevées. II y avait une relation forte entre les variations de chacun des éval uateurs et les opérations mathématiques utilisées dans les calculs des formules d'éval uation. La méthode Helliwell qui multiplie ensemble tous les facteurs d'évaluation produisait immanquablement les variations les plus élevées entre les évaluateurs La méthode ST EM qui additionne tous les facteurs ensembles produisait immanquablement les varia tions les plus fai bles entre les évaluateurs M inimiser le nombre des opérations de multiplication employées dans les formules est une façon effective de diminuer les variations entre les évaluateurs; mais en faisant cela, l'influence de chacun des facteurs peut être diminuée de façon trop prononcée.

Z usammenfassung. Von fünf unterschiedlichen Ländern wurden die Werte von verschiedenen Baumuntersuchungsmethoden verglichen (CTLA-U SA, STEM - N ew Zealand, $\mathrm{H}$ elliwell-Great Britain, $\mathrm{N}$ orma G ranada Spain, Burnley-A ustralia). $\mathrm{N}$ eun Individuen untersuchen die gleichen sechs Bäume mit allen fünf $M$ ethoden. CTLA und Burnley produzierten die niedrigsten Werte und N orma Granada war eine der höchsten. Es gab eine starke R elation zwischen den U nterschieden unter den Anwendern und den mathematischen 0 perationen, die angewendet wurden, um auf die Ergebnisse in den Vordrucken zu kommen. Die H elliwell-M ethode, welche alle Faktoren miteinander multipliziert, verursachte die größten U nterschiede zwischen den A nwendern. STEM addiert alle Faktoren zusammen und verursacht die geringsten U nterschiede unter den Anwendern. D as M inimieren der $M$ ultiplikationen, die in den einzelnen $M$ ethoden verwendet wurden, reduzierte die $\mathrm{U}$ nterschiede unter den Anwendern, aber der Einfluss von individuellen Bewertungskriterien wird ebenfalls reduziert.

Resumen. Se estudiaron los métodos para calcular el valor de los árboles en cinco países diferentes (CTLA-U SA, ST EM - N ew Z ealand, H elliwell- G reat B ritain, N orma G ranada Spain, BurnleyAustralia). Se evaluaron nueve ejemplares de seis árboles usando los cinco métodos LOS métodos CTLA y Burnley produjeron consistentemente los valores más bajos, y los valores del método N orma Granada fueron con frecuencia los más altos. Existe una relación estrecha en la variación entre los evaluadores y las operaciones matemáticas usadas en los cálculos de las fórmulas. EI método H elliwell, el cual multiplica todos los factores, produjo la variación más alta entre evaluadores. STEM , el cual suma todos los factores, produjo la variación más baja. U na buena forma de reducir esta variación entre evaluadores es minimizar el número de operaciones de multiplicación usadas en las fórmulas. Sin embargo, esto puede reducir demasiado la influencia de los factores individuales. 